UNTAG Law Review (ULREV)

Volume 2, Issue 1, May 2018, PP 21-30

ISSN 2549-4910 (online) \& ISSN 2579-5279 (print)

http://jurnal.untagsmg.ac.id/indeks.php/ulrev/indeks

www.fakhukum.untagsmg.ac.id

\title{
LEGAL PROTECTION OF INTELLECTUAL PROPERTY RIGHTS OVER TRADITIONAL KNOWLEDGE ACQUISITION AGAINST ECONOMIC BENEFITS
}

\author{
Karlina Sofyarto \\ Lecturer of Faculty Law, Diponegoro University \\ Email: karlinasofyarto.003@gmail.com
}

\begin{abstract}
Traditional knowledge is the result of innovation and creation of human beings both in terms of knowledge, art, and literature. Traditional knowledge can be utilized economically for the betterment and prosperity of society. The research method used is descriptive analytical with Juridical normative specification. Indonesia's Efforts in protecting intellectual property on traditional knowledge in Indonesia is the Indonesian government is preparing the Draft Law on Traditional Knowledge and Traditional Cultural Expression. Other Efforts that can be done is through the way of inventory or documentation of traditional knowledge in a region and can be done by publishing the traditional knowledge as Widely as possible. The underlying factors of traditional knowledge have not been optimally utilized as economic resources namely the lack of public knowledge about the protection of traditional knowledge and the cost of producing intellectual property is high enough.
\end{abstract}

Keywords: Economy, Intellectual Property Rights, Traditional Knowledge

\section{INTRODUCTION}

Indonesia as an archipelago with numerous ethnic groups with diverse customs, art and culture has a huge potential in terms of traditional knowledge. The extraordinary potential of culture is essentially a national asset that must be protected and preserved the existence and development by the state because it has a very high economic value that can benefit society. Information obtained by the public in the interpretation of the needs of nature and the environment as well as the knowledge gained by the community as a result of interaction of ecological, social, and cultural called "Traditional Knowledge. ${ }^{1}$

1 Charles R. McManis, 2007, Biodiversity and the law: Intellectual Property, Biotechnology and Traditional Knowledge, Earthscan, London, p 277. 
Traditional Knowledge included in the scope of work inteltual sources from ede, ideas, or the discovery of a group of countries. The scope of traditional knowledge includes tradition-based literary, artistic or scientific works, performances, inventions, scientific discoveries, designs, marks, names and symbols, undisclosed information and all of the innovations and creations based on other traditions caused by intellectual activity in the areas the industrial, scientific, literary or artistic.

World Intellectual Property Organization (WIPO) defines traditional knowledge as follows:

"knowledege, know-how, skills and practices that are developed, sustained and passed on from generation to generation within a community, Often forming part of its cultural or spiritual identity". ${ }^{2}$

In the document WIPO, traditional knowledge is not limited to one particular knowledge but it refers to a very wide range of knowledge, which separates traditional knowledge with other knowledge that is their attachment to a particular community and characteristic that gives traditional nature. Traditional knowledge by WIPO classified as: knowledge of agriculture (agricultural knowledge), scientific knowledge (scientific knowledge), knowledge of the environment (ecological knowledge), knowledge of drugs including medicine and healing (Including knowledge related medicines medicine andremedies), related knowledge of biodiversity (biodiversity-related knowledge), expression in music, dance, song, crafts, elements of language and cultural objects that move. ${ }^{3}$ Traditional knowledge within the scope of the intellectual work that comes from ideas, ideas, or the discovery of community groups. Traditional knowledge is the identity and the identity of the Indonesian nation that can be used economically for the progress and welfare of the community. Traditional knowledge (traditional knowledge) is the term used WIPO intended to provide the finish line to a work culture that is both traditional and owned by traditional communities. The process of traditional knowledge is the result of human innovation and creation both in terms of knowledge, art and literature.

Emerging issues at this time within the scope of IPR assessment that the legal protection of intellectual property generated by indigenous or traditional communities in Indonesia. Traditional knowledge is closely related to intellectual property and present in almost all branches of intellectual property rights, such as copyrights, patents, trademarks, and trade secrets. The past few years when the issue of allegations of the claim for reog Ponorogo dance and Pendet by Malaysia, was widely publicized in the media. However, in fact this issue has

2 World Intellectual Property Organization, accessed via http ://www.wipo.int/tk/en/tk/index.html, downloaded January 16, 2018.

3 Desi Churul Aini, 2012, Assessing Conditions Juridical Protection of Traditional Knowledge in International Law, Graduate Thesis, University of Indonesia, pp 38-39, 
become a matter of debate at the international level since 2001, when the first session of the Intergovernmental Committee on Intellectual Property and Genetic Resources, Traditional Knowledge and Folklore (IGC GRTKF) was held at WIPO headquarters in Geneva, Switzerland.

The discussion about the need for protection of traditional knowledge has become an important issue in the meetings of the IPR Council (Council for Trade-Related Aspects of Intellectual Property Rights) in the WTO. The existence of a long debate is more regarding the necessity of protection of traditional knowledge are regulated separately or incorporated into legislation HKI each member state which becomes a push-pull of interests between developed countries (developed countries) and developing countries (developing country) in the case protection of traditional knowledge.

The works of traditional art, traditional techniques that have long lived in a traditional society, is regarded as a valuable economic asset, such as tempeh patent case in the United States. Tempe which is Indonesian traditional food with raw materials by soy flour and fried and sold alongside a road turns right to the patent is owned by the United States.

Factually, there is no realization of profit sharing for the community of owners of traditional knowledge. ${ }^{4}$ The government is responsible to protect, not only as part of the traditional knowledge of biodiversity, but also traditional knowledge as belonging to the local community. That is, given the integral protection against material and form of ownership. ${ }^{5}$

Based on this background, the formulation of the problem is as follows: How does Indonesia's efforts to protect intellectual property rights over traditional knowledge? As well as the factors underlying what traditional knowledge has not been used optimally as an economic resource? The goal is that the Indonesian government immediately legalize the legislation related to intellectual property protection of traditional knowledge and the public more aware of the traditional knowledge by registering to the Ministry of Law and Human Rights (Kemenkumham).

\section{METHODS}

This type of research will be used in the writing of this law is normative research. Normative legal research is legal research done by researching library materials or secondary data. ${ }^{6}$

4 Vienna Puspitasari, 2014, the legal protection of the traditional knowledge with the licensing system: state perspective, Journal of Legal Sciences of Padjadjaran, Vol 1, p 3.

5 Laura Westra, 2008, the Environmental Justice and the Rights of Indigenous Peoples: International and Domestic Legal Perspectives, Earthscan, London, p. 36.

6 Soerjono Soekanto and Sri Mamuji, 2006, Normative Legal Research A Brief Overview,PT. King Grafindo Persada, Jakarta, p 13. 
Research conducted by the authors to have a descriptive nature. A descriptive study was intended to provide the data as thoroughly as possible about the people, circumstances or other symptoms. ${ }^{7}$ In this study the sources of data used are secondary data. Secondary data sources are data obtained not directly from the public but from the material documents, legislation, reports, archives, literature, and the results of other studies that support the primary data source. Analysis of the data were qualitatively using deductive approach and in the discussion that adapted to the subject matter presented for the conclusion of the issues studied.

\section{DISCUSSION}

Indonesian government's efforts to protect intellectual property rights over traditional knowledge protection issues of traditional knowledge as part of the IPR to public attention and various international organizations. WIPO, based in Geneva, Switzerland gives a mandate to the members to discuss Genetic Traditional Knowledge and Folklore (GRTKF) in international forum. IPRs in the global order is seen as trade issues that have relevance to the relationship between the three important aspects, namely intellectual property, commercialization, and legal protection. This relates to traditional knowledge possessed or controlled and used by a community, society, or certain ethnic groups that are hereditary and continues to grow in accordance with the development environment.

In the document WIPO, traditional knowledge is not being restricted to one specific knowledge but it refers to a very broad range of knowledge. Traditional knowledge is an important knowledge of an identity within a community, so that essentially traditional knowledge is innovation, creativity, and cultural expressions are generated and maintained for generations by indigenous peoples, local communities, or individuals in the local community of a country.

The protection of IPR is basically giving a monopoly, and the monopoly rights of IPR owners can enjoy the economic benefits of intellectual property gets. Various IPR legislation in fact unable to protect traditional knowledge and wisdom(traditionalknowledge and genius). The legal basis for the public demands of those who use traditional knowledge commercially without permission has not been set explicitly in the legislation of IPR in Indonesia. The provisions of Article 10, paragraph 2 of Law No. 19 Year 2002 concerning Copyrights limited to regulating folklore. It should not include copyright protection of traditional knowledge, which means that the position of traditional knowledge society vulnerable to exploitation by others.

Protection of knowledge traditional in Indonesia are also contained in the legislation besides the Law of IPR. Law No. 5 of 1994 on the ratification of the Convention on Biological

7 Soerjono Soekanto 2005, Introduction to Legal Research,UI Press, Jakarta, 2005, p 10. 
Diversity(UnitedNations Convention on Biodiversity), Article 8 J UNCBD mentioned that the signing of the convention are obliged to respect, protect, maintain knowledge, innovations and practices of indigenous and local communities that reflect the style traditional characterized life, according to the conservation and sustainable use of biological diversity and promote their wider application with the approval and involvement of holders of such knowledge, innovations and practices and encourage the equitable sharing of the benefits arising from the empowerment knowledge and innovation.

In general there are five main reasons traditional knowledge should be protected, namely:

1) Justice(equity)

A fairness and justice if the owners of traditional knowledge his knowledge exploited and commercialized for revenue sharing or compensation is both monetary and nonmonetary;

2) Conservation(conservation)

Protection of traditional knowledge, means also for the maintenance of environmental protection, biodiversity, and sustainable agricultural practices;

3) Maintaining traditional practices and culture(preservation)

The protection of traditional knowledge can be used to increase the value and public trust either inside or outside the community of the values of traditional knowledge;

4) Prevent misuse by unauthorized parties or avoid bio-piracy (avoiding bio-piracy)

Traditional knowledge protection is one way to reduce the practice of bio-piracy,while ensuring fairness and equal treatment between owners and users of traditional knowledge. According to Moni Wekesa to prevent misuse of traditional knowledge, at least there are three important things to note: ${ }^{8}$

a) The documentation of traditional knowledge is done through the development of databases of traditionalknowledge;

b) Obligation requirement to specify the origin of the material to be applied for legal protection through the intelectualproperty;

c) For those who would seek legal recognition through IPRs, should be able to show proof of approval of the use, disposition of property, as well as distribution of profits of the owners of traditional knowledge.

8 Djumhana Muhammad, R. Djubaedillah, 2014, the Intellectual Property Rights of History, Theory, and Practice inIndonesia,PT, Citra Aditya, Bandung, $\mathrm{p} 8$. 
5) As the promotion of the use and importance of the development of traditional knowledge(promotion of its use) ${ }^{9}$

In addition to the protection by restricting access to traditional knowledge, the government should aim to support the use of traditional knowledge itself, and develop efforts aimed at preventing abuse.

Referring to Duffed, in order to protect traditional knowledge, there are at least three models of protection that can be developed, namely: ${ }^{10}$

\begin{tabular}{|c|c|c|}
\hline $\begin{array}{l}\text { Utilizing Rule Existing } \\
\text { Previous }\end{array}$ & $\begin{array}{l}\text { Modify / Additional } \\
\text { Rules / } \\
\text { Supplementary }\end{array}$ & $\begin{array}{l}\text { Develop Regulation } \\
\text { Characteristically } \\
\text { Particular }\end{array}$ \\
\hline Customary Law & $\begin{array}{l}\text { Codification and } \\
\text { Formal } \\
\text { Recognition Provisions } \\
\text { Of The Law } \\
\text { Customary. }\end{array}$ & ----- \\
\hline $\begin{array}{c}\text { Contracts, Transfer } \\
\text { Agreements Are } \\
\text { Balanced, } \\
\text { And The Concept Of } \\
\text { Public Law } \\
\text { And Other Civil }\end{array}$ & $\begin{array}{c}\text { And Access Agreements } \\
\text { For Theresults }\end{array}$ & $\begin{array}{l}\text { Provisionin The } \\
\text { Management Of } \\
\text { Biodiversity With } \\
\text { Obligations } \\
\text { On Traditional } \\
\text { Knowledge, } \\
\text { Access To Legislation }\end{array}$ \\
\hline $\begin{array}{c}\text { Intellectual Property } \\
\text { Rights Law }\end{array}$ & $\begin{array}{c}\text { Certificate Of Origin } \\
\text { Of Matter } \\
\text { Prior Informed Consent (Pic), } \\
\text { And Others }\end{array}$ & $\begin{array}{l}\text { A New Category } \\
\text { In Intellectual } \\
\text { Property Law. }\end{array}$ \\
\hline
\end{tabular}

The concept of the protection of traditional knowledge as described Duffield in line with protection model developed by WIPO. WIPO generally describe two models, namely protection:

1) Protection and preventive (defensive protection)

9 Carlos M. Correa, Protection and Promotion of Traditional Medicine Implication for Public Health in Developing Countries, http://apps.who.int/medicine docs / pdf/s4917e.pdf, accessed January 102018.

10 Karin Timmermans, 2001 'TRIPs, CBD and Traditional Medicine: Concept and Question", Report of an ASEAN Workshop on the TRIPS Agreement and TraditionalMedicine.Jakarta, p 32. 
Defensive protection refers to efforts aimed at preventing the granting of IPRs on traditional knowledge by the other party without the knowledge and permission of the owners of traditional knowledge. Defensive protection of traditional knowledge influence the patent registration in terms of disclosure obligations on the origin of genetic resources and / or traditional knowledge associated with the invention.

2) Protection of positive(positiveprotection)

Positive protection can be done in two forms the legal quagmire, with effective use of legislation related to intellectual property rights or through the establishment of special laws.

Intellectual property protection of traditional knowledge, the Indonesian government is preparing a rule sui generis is divided into three Bills as follows: Bill on Traditional Knowledge and Traditional Cultural Expressions, the Bill on the Protection and Management of Genetic Resources, and Bill on Biodiversity. The protection of traditional knowledge they require a fairly long time to implement.

Positive role of the state in the fulfillment of the right to culture, as is proposed by Wheeler, the state was able to develop a collective capacity for the enforcement of human rights through legislation and institutional interventions are effective. ${ }^{11}$ This is what makes the country very strategic role in the fulfillment of cultural rights because the country has a functional completeness to enforce these rights as part of the right legal basis. Protection of intellectual property rights over traditional knowledge as communal rights of local communities, is required by authorized institutions to organize, manage, and coordinated the protection of traditional knowledge within the framework of state responsibility.

Institutions in the protection of traditional knowledge is required to support the implementation of access and benefit-sharing for the utilization of traditional knowledge. In efforts to protect intellectual property on traditional knowledge, there are several agencies, including: the Ministry of Environment, Ministry of Foreign Affairs, Ministry of Research and Technology, as well as the Directorate General of Intellectual Property Rights. Legal protection of traditional knowledge is needed by developing countries, because the protection is considered as the measures taken to ensure the survival of cultural heritage objects and communal creativity. ${ }^{12}$ Efforts should be made to protect the property rights over traditional knowledge, namely by means of an inventory. Inventory or documentation of traditional

11 Jack Donnelly, 2003, In Defense of the Universal DeclarationModel,Gene M.Lyons and James Mayall, International Human Rights in the 21st Century: Protecting the Rights of Groups, Boston, Rowman \& Littlefield Publishers,p 16.

12 OK, Saidin, Legal Aspects of Intellectual Property Rights, PT. King Grafindo Persada, Jakarta, $2006, \mathrm{p} 78$. 
knowledge is the data collection activities on a traditional knowledge in a region. In addition, it can be done in a way to publish the traditional knowledge widely. Legal protection is intended not only to guarantee legally but also economically. Factors underlying traditional knowledge has not been used optimally as an economic resource A knowledge on the traditional work of the spoken knowledge hereditary and largely in ways that have not been written. The scope of traditional knowledge of indigenous / traditional is inclusive, meaning that all parties can utilize free of traditional just knowledge if developed continuously and are guaranteed legal protection it will have a high economic value and can boost the economy in Indonesia. Property rights over traditional knowledge is fundamental economy of a nation. Economic progress of a nation can be seen from how much intellectual property rights owned by the nation. This is a factor Indonesian government should provide special protection of traditional knowledge from being misused by foreign countries.

Constraints are the main reason why the protection of traditional knowledge can not be utilized optimally, namely regulation that has not fully support the implementation of traditional knowledge, the low awareness of the public to register a work or thinking, lack of documentation of data, as well as the characteristics of traditional knowledge, which were often communal. Traditional knowledge is often associated with the use and applications of genetic resources, biological, and natural or management and conservation of natural resources and the environment have the values and the economic, commercial and cultural. ${ }^{13}$

On IPRs are the two specific rights, the economic rights (economic right)and moral rights(moralrights), in addition to their social function. ${ }^{14}$ Economic rights is the right to gain intellectual property. This right is in the form of profits earned money for his own use of intellectual property rights, or for use by other parties under license. This is because IPR can be the object of trade in the business world. Economic rights are transferable. While the moral rights are rights that protect private interests (reputation) of the creator or inventor.

The problem of IPR protection against Indigenous Knowledge in Indonesia, almost lies in every aspect such as the lack of public knowledge about the conception of IPR protection, high cost and slow pace of bureaucracy in realizing Plan Protection Act and Utilization of Intellectual Property Traditional Knowledge and Traditional Cultural Expressions (RUU PT \& EBT) to Act (the Act). If all traditional knowledge can be gained formal recognition from the state without any constraints, then the local community as the owners of traditional knowledge will benefit economically as well as legal recognition both nationally and internationally.

13 Muhammad Ahkam Subroto and Suprapedi 2005, Exploration Concept of Intellectual Property to foster innovation,Perss LIPI, Jakarta, p 32.

14 Muhammad Abdul kadir., 2001, Study of Economic Law Intellectual Property Rights,PT , Citra Aditya Bakti, Bandung, p 2. 
Profit sharing for the utilization of traditional knowledge has broad economic dimension. Traditional knowledge is intended as an economic resource that can generate profits. The economic benefits of not-necessarily perceived by the owner if the owner is not using its economic rights. If traditional knowledge with a little touch of the newly patented innovations, the economic benefit will only be owned and enjoyed by the IPR holder. Even traditional society as the original owner if you want to re-use their traditional knowledge must go through certain procedures and burdened with high costs.

Some things that cause traditional society has not been able to enjoy the economic benefits of traditional knowledge that is the nature of indigenous peoples' communal will always put the common interest rather than personal interests, fees for produce intellectual property is very high, permits the manufacture of products that are quite difficult, competition is high enough , the absence of institutions that facilitate and control so that the intellectual property is used as a product on the market.

\section{CONCLUSION}

Protection of traditional knowledge is very important for Indonesia, where traditional knowledge has a role in the economic and social life of the community. IPR legal protection against traditional knowledge has not been discussed in detail and systematically in Indonesia. The setting of traditional knowledge in IPR example Act Copyright Act and arrangements regarding Geographical Indications in the Trademark Act have not been entirely effective to implement. If the traditional knowledge of IPR protection against optimal, then it will be a potential foreign exchange earnings that provide welfare to society.

Factors that cause traditional knowledge has not been used optimally as an economic resource that is the nature of indigenous peoples' communal will always put the common interest rather than personal interests, lack of local knowledge about traditional knowledge, costs to produce intellectual property is very high, the permission to manufacture enough product difficult, competition is high enough, the absence of institutions that facilitate and control so that the intellectual property is used as a product on the market.

\section{SUGGESTION}

For Indonesian government that the regulation system of protection of traditional knowledge was more emphasized, because the laws that exist today are still not regulated comprehensively. This is done to improve the economy and prosperity of society. To the people of Indonesia to be more concerned and aware of the importance of traditional knowledge to preserve and share the success of efforts to protect traditional knowledge. 


\section{REFERENCES}

Abdul Kadir Muhammad, 2001, Assessment of Economic Law of Intellectual Property Right, PT. Citra Aditya Bakti, Bandung.

Andy Noorsaman Soemeng, "National Strategy in the Development of Intellectual Property Rights System", Jakarta, June 24, 2008

Carlos M Correa, 2002, The Protection and Promotion of Traditional Medicine Implication for Public Health in Developing Countries, Retrieved from http: //apps.who. int / medicine docs / pdf/s4917e.pdf,downloaded January 10, 2018

Charles R McManis, 2007, Biodiversity and the law: Intellectual Property, Biotechnology and Traditional Knowledge, Earthscan, London.

Desi Churul Aini, 2012, Assessing Conditions Juridical Pelrindungan Traditional Knowledge in International Law, University of Indonesia.

Jack Donnelly, 2003, "In Defense of the Universal Declaration Model", Gene M.Lyons and James Mayall, International Human Rights in the 21st Century: Protecting the Rights of Groups,Boston, Rowman \& Little field Publishers.

Laura Westra, 2008, The Environmental Justice and the Rights of Indigenous Peoples: International and Domestic Legal Perspectives, Earthscan, London.

Muhammad Ahkam Subroto and Suprapedi 2005,"IntellectualProperty Concept Exploration to fosterinnovation",Perss LIPI, Jakarta.

Muhammad Djumhana \& R. Djubaedillah, 2014, the Intellectual Property Rights of History, Theory, and Practice in Indonesia,PT. Citra Aditya, Bandung.

Soerjono Soekanto \& Sri Mamuji 2006, Normative Legal Research A Brief Overview,PT. King Grafindo Persada, Jakarta.

Soerjono Soekanto 2005, Introduction to Legal Research,UI Press, Jakarta.

Timmermans, Karin, 2001, 'TRIPs, CBD and Traditional Medicine: Concept and Question ", Report of an ASEAN Workshop on the TRIPS Agreement and Traditional Medicine, Jakarta.

Vienna Puspitasari, 2014, The Legal Protection Of The Traditional Knowledge With The Licensing System: The Perspective OfThe Welfare State. Padjadjaran Law Journal,Vol.1. 